\title{
Application of stable isotope analysis to differentiate shrimp extracted by industrial fishing or produced through aquaculture practices
}

\author{
Julián Gamboa-Delgado, César Molina-Poveda, Daniel Enrique Godínez-Siordia, \\ David Villarreal-Cavazos, Denis Ricque-Marie, and Lucía Elizabeth Cruz-Suárez
}

\begin{abstract}
Carbon and nitrogen stable isotope values were determined in Pacific white shrimp (Litopenaeus vannamei) with the objective of discriminating animals produced through aquaculture practices from those extracted from the wild. Farmed animals were collected at semi-intensive shrimp farms in Mexico and Ecuador. Fisheries-derived shrimps were caught in different fishing areas representing two estuarine systems and four open sea locations in Mexico and Ecuador. Carbon and nitrogen stable isotope values $\left(\delta^{13} \mathrm{C}_{\mathrm{VPDB}}\right.$ and $\left.\delta^{15} \mathrm{~N}_{\mathrm{AIR}}\right)$ allowed clear differentiation of wild from farmed animals. $\delta^{13} \mathrm{C}_{\mathrm{VPDB}}$ and $\delta^{15} \mathrm{~N}_{\mathrm{AIR}}$ values in shrimps collected in the open sea were isotopically enriched $(-16.99 \%$ ond $11.57 \%$ ), indicating that these organisms belong to higher trophic levels than farmed animals. $\delta^{13} \mathrm{C}_{\mathrm{VPDB}}$ and $\delta^{15} \mathrm{~N}_{\mathrm{AIR}}$ values of farmed animals $(-19.72 \%$ and $7.85 \%$, respectively) partially overlapped with values measured in animals collected in estuaries $(-18.46 \%$ ond $5.38 \%$, respectively). Canonical discriminant analysis showed that when used separately and in conjunction, $\delta^{13} \mathrm{C}_{\mathrm{VPDB}}$ and $\delta^{15} \mathrm{~N}_{\mathrm{AIR}}$ values were powerful discriminatory variables and demonstrate the viability of isotopic evaluations to distinguish wild-caught shrimps from aquaculture shrimps. Methodological improvements will define a verification tool to support shrimp traceability protocols.
\end{abstract}

Résumé : Les valeurs d'isotopes stables du carbone et de l'azote ont été déterminées pour des crevettes à pattes blanches (Litopenaeus vannamei) du Pacifique dans le but de distinguer les animaux issus de pratiques aquacoles d'animaux issus du milieu naturel. Des animaux d'élevage ont été prélevés dans des installations de culture semi-intensive de crevettes au Mexique et en Équateur. Les crevettes issues de la pêche ont été prises dans différentes zones de pêche représentant deux systèmes estuariens et quatre emplacements en mer libre au Mexique et en Équateur. Les valeurs d'isotopes stables du carbone et de l'azote $\left(\delta^{13} C_{V P D B}\right.$ et $\delta^{15} \mathrm{~N}_{\mathrm{AIR}}$ ) ont permis de distinguer clairement les animaux sauvages des animaux d'élevage. Les valeurs de $\delta^{13} \mathrm{C}_{\mathrm{VPDB}}$ et $\delta^{15} \mathrm{~N}_{\mathrm{AIR}}$ des crevettes prélevées en mer libre étaient enrichies $(-16,99 \%$ et $11,57 \%$ ), ce qui indique que ces organismes occupent des niveaux trophiques plus élevés que les animaux d'élevage. Les valeurs de $\delta^{13} C_{\mathrm{VPDB}}$ et $\delta^{15} \mathrm{~N}_{\mathrm{AIR}}$ des animaux d'élevage $(-19,72 \%$ et $7,85 \%$, respectivement) chevauchent partiellement les valeurs mesurées pour les animaux prélevés dans des estuaires (-18,46\%。 et 5,38\%, respectivement). L'analyse canonique discriminante a démontré que, utilisées séparément et ensemble, les valeurs de $\delta^{13} \mathrm{C}_{\mathrm{VPDB}}$ et $\delta^{15} \mathrm{~N}_{\mathrm{AIR}}$ constituent des variables discriminantes puissantes. Elle démontre également l'utilité des évaluations isotopiques pour distinguer les crevettes prises en milieu naturel des crevettes d'élevage. Des améliorations méthodologiques définiront un outil de vérification pour appuyer les protocoles de traçabilité des crevettes. [Traduit par la Rédaction]

\section{Introduction}

The expanding commercialization of products derived from fisheries and aquaculture have generated the need to authenticate the production method of several products. New strict legislations have required that seafood products display information related to the origin and production method of aquatic organisms traded in specific regions (EC 2001). On the other hand, shrimp exports must comply with information concerning traceability of fisheries and aquaculture products (EC 2002). The fraudulent misdescription of food contents on product labels is a widespread problem in which products from different animal products are packed and sold, but correspond to different species than those indicated on the labels (Woolfe and Primrose 2004). Similarly, batches of farmed seafood (including shrimp) have been deliber- ately mislabelled as wild-caught seafood and vice versa, in order to avoid sanctions, wild-caught seafood has been mislabelled as farmed during fishing ban periods (COFEMER 2013; Jacquet and Pauly 2008; NOAA 2011). In view of this situation, steps are being taken to implement additional survey and control protocols for the seafood industry. For example, in Mexico, the Secretariat of Agriculture, Livestock, Rural Development, Fisheries and Food (SAGARPA) has recently proposed a Mexican Official Standard (NOM-047-PESC-2012) to define procedures aimed to implement a paper-based traceability system that allows identifying farmed and wild shrimp (COFEMER 2013). Although careful traceability of products through the seafood production chain leads to effective assessment of production method, the application of analytical methods to validate product authenticity assists in verifying the traceability process and helps detecting deliberate mislabelling

Received 6 January 2014. Accepted 9 June 2014.

Paper handled by Associate Editor Bronwyn Gillanders.

J. Gamboa-Delgado, D. Villarreal-Cavazos, D. Ricque-Marie, and L.E. Cruz-Suárez. Programa Maricultura, Departamento de Ecología, Facultad de Ciencias Biológicas, Universidad Autónoma de Nuevo León, A.P. F-67, San Nicolás de los Garza, Nuevo León, México C.P. 66451.

C. Molina-Poveda. GISIS S.A. km 6.5 vía Duran-Tambo, Duran, Ecuador.

D.E. Godínez-Siordia. Departamento de Estudios para el Desarrollo Sustentable de Zonas Costeras, Centro Universitario de la Costa Sur, Universidad de Guadalajara, Gómez Farías 82, San Patricio-Melaque, Jalisco, México C.P. 48980.

Corresponding author: Julián Gamboa-Delgado (e-mail: julian.gamboad@uanl.mx and jgam97@yahoo.com). 
(Vinci et al. 2013). On the other hand, issues derived from other environmental concerns (e.g., failure to implement turtle excluder devices in shrimp trawlers) have led to shrimp import prohibitions (USDS 2010) that only apply to open-sea-caught shrimp, but not to farmed shrimp or shrimp extracted from estuaries through artisanal fishing.

The Pacific white shrimp (Litopenaeus vannamei) is the dominant marine species produced through aquaculture practices, and farm production has surpassed production derived from wild catches. In the Western Hemisphere, semi-intensive shrimp farming is the current predominant shrimp production method (CONAPESCA 2010; Stern and Sonnenholzner 2011). As shrimp represents one of the most important commercialized commodities for Mexico (184123 tonnes (t) of shrimp produced in 2011; CONAPESCA 2012) and Ecuador (208 $872 \mathrm{t}$ of exported shrimp in 2012, representing \$1.2 billion USD; CNA 2012), positive effects such as assisting in the certification of production method and discouraging illegal fishing are expected from shrimp traceability and verification protocols. Discriminating seafood derived either from fisheries or aquaculture can be achieved by identifying and measuring a specific tracer (Moretti et al. 2003). The relatively new science of food forensics (Primrose et al. 2010) is employing a range of developing isotopic techniques that have allowed detecting adulterated and counterfeit food and pharmaceutical products (Kropf et al. 2010; Felton et al. 2011). In food authenticity studies, carbon, nitrogen, oxygen, and (or) hydrogen are the elements more frequently analyzed in a specific sample to determine their isotopic proportions (e.g., ${ }^{13} \mathrm{C} /{ }^{12} \mathrm{C}$ ). The isotopic signature of a plant or animal reflects the isotopic profile of its surrounding environment (available nutrients, soil and water characteristics). Hence, studies applying stable isotopes have been conducted on different organisms to elucidate production method and geographical origin (Kropf et al. 2010; Peterson and Fry 1987). The nitrogen isotope value of a wild animal can indicate its trophic position, as animal consumers have a tendency to accumulate the heavier isotopes through a discriminating effect of the different enzymatic pathways preferentially incorporating the heavier isotopes, while the lighter isotopic forms are excreted (Martínez del Rio and Wolf 2005; Minagawa and Wada 1984). Farmed organisms are influenced by different environmental factors, stocking densities and feeding regimes as compared with wild animals (Arechavala-Lopez et al. 2013). The diet of wild animals might experience strong seasonal variations in composition and availability of trophic elements. Such trophic elements occupy higher trophic positions than the dietary items available and (or) supplied to farmed organisms. Such dietary attributes frequently confer specific isotopic values to wild and farmed animals. As these isotopic differences are substantial and influenced by diet and (or) trophic level, they have been previously employed to distinguish the production method of European seabass (Dicentrarchus labrax), seabream (Sparus aurata), and Atlantic salmon (Salmo salar) (Bell et al. 2007; Dempson and Power 2004; Moreno-Rojas et al. 2007; Serrano et al. 2007). Animals growing in aquaculture systems operating under semi-intensive and intensive rearing conditions derive major proportions of nutrients from the supplied feed, which modifies the animal's isotopic profiles (Nunes et al.1997; Gamboa-Delgado 2014). In this context, the present study examined the use of dual stable isotope analysis as a tentative tool to authenticate samples of Mexican and Ecuadorian shrimp under the hypothesis that the isotopic values of semi-intensively farmed shrimp are influenced by the isotopic signatures of the formulated diets and the pond's natural productivity. Therefore, farmed animals will show significantly different isotopic signatures as compared with isotopic values present in wild animals caught by industrial fishing on the open sea.

\section{Material and methods}

\section{Study areas and sample collection}

Wild and farmed individuals of Pacific white shrimp were collected at different locations in Mexico and Ecuador. As shown in Fig. 1, wild shrimp (estuary and open sea) were collected in the Pacific Ocean. In Ecuador, wild shrimp were obtained off the coast of Esmeraldas Province (Southeast Pacific, FAO fishing area 87), while in Mexico, wild shrimp were representative of an area spanning through the states of Sinaloa and Nayarit (Eastern Central Pacific, FAO fishing area 77). Two batches of shrimps from open sea were obtained from fishermen. Animals were caught approximately 25 miles $(1$ mile $=1.609 \mathrm{~km})$ off the coast of Nayarit and 33 miles off the coast of Sinaloa. An additional batch of wild shrimp (Litopenaeus setiferus) was collected in the Gulf of Mexico, approximately 42 miles off the coast of Tamaulipas (Western Central Atlantic, FAO fishing area 31). In Mexico, estuarine shrimps were collected from three different locations of the northern area of a coastal lagoon complex (Marismas Nacionales) located between the states of Sinaloa and Nayarit, while in Ecuador, shrimp were sampled in a mangrove system in the Esmeraldas Province. Farmed animals (Table 1) were obtained from nine shrimp ponds belonging to five farms operating at semi-intensive production levels (ponds receiving inorganic fertilizers, stocked with shrimp densities from 11 to 30 individuals $\cdot \mathrm{m}^{-2}$, and supplied with formulated feeds having $28 \%$ to $35 \%$ crude protein). In Ecuador, farmed animals were collected in a semi-intensively managed farm in La Tola, Esmeraldas Province. Farmed Mexican shrimp batches were collected in four semi-intensive farms located on the Pacific seaboard (Sonora and Jalisco states) and on the Gulf of Mexico seaboard (inland semi-intensive farm, Veracruz state). Additional sampling was conducted in one intensively managed farm producing L. vannamei at high stocking densities (50 individuals $\cdot \mathrm{m}^{-2}$ ) under low salinity water conditions ( $1 \mathrm{~g} \cdot \mathrm{L}^{-1}$, Colima state). All wild shrimp samples caught on open sea were represented by adult individuals, and some female shrimps showed advanced ovarian development. Most samples of farmed shrimp consisted of juveniles and subadult individuals (Table 1). Species confirmation was assisted by identification keys (Pérez-Farfante 1988).

\section{Sample pretreatment and stable isotope analysis}

Sampled shrimp were transported under cold or freezing conditions and once in the laboratory were weighed and dissected. The exoskeletons, hind gut, and gonads (if present) were removed, and samples of abdominal muscle tissue were obtained by cutting triangular sections from the ventral side of the second abdominal segment. Dissected muscle tissue samples were rinsed in distilled water and dried in a convection oven $\left(60^{\circ} \mathrm{C}\right)$. Samples were manually ground to a fine powder and were not lipid-extracted, as shrimp muscle contains low lipid levels. Bodin et al. (2007) demonstrated that $\delta^{13} \mathrm{C}_{\mathrm{VPDB}}$ and $\delta^{15} \mathrm{~N}_{\mathrm{AIR}}$ values in muscle tissue of decapod crustaceans experience minimal changes after solvent treatment; therefore, the use of untreated muscle samples for isotopic analysis has been recommended (Stenroth et al. 2006). Samples of ground muscle tissue (900 to $1100 \mu \mathrm{g}$ ) were individually packed in tin cups (Elemental Microanalysis Ltd., UK) and organized in 96-well microplates. Ten samples of farmed shrimp were selected from each batch, while up to 21 samples were analyzed for batches of wild-caught shrimp, as a higher isotopic variability was expected in wild animals. This higher isotopic variability in wild specimens is conferred by the higher number of trophic elements available in the natural environments in comparison with the food sources available for farmed shrimps. Samples were analyzed at the Stable Isotope Facility of the University of California (Davis, California, USA) using a PDZ Europa ANCA-GSL elemental analyzer interfaced to a PDZ Europa 20-20 isotope ratio mass spectrometer (IRMS, Sercon Ltd., Cheshire, UK). Samples were combusted at $1000{ }^{\circ} \mathrm{C}$ in a reactor packed with chromium oxide and silver-copper oxide. 
Fig. 1. Maps of Mexico and Ecuador showing the locations where shrimp batches were collected to validate production method by means of dual stable isotope analysis. All samples were represented by the species L. vannamei, with the exception of wild shrimp (L. setiferus) sampled in the Gulf of Mexico.

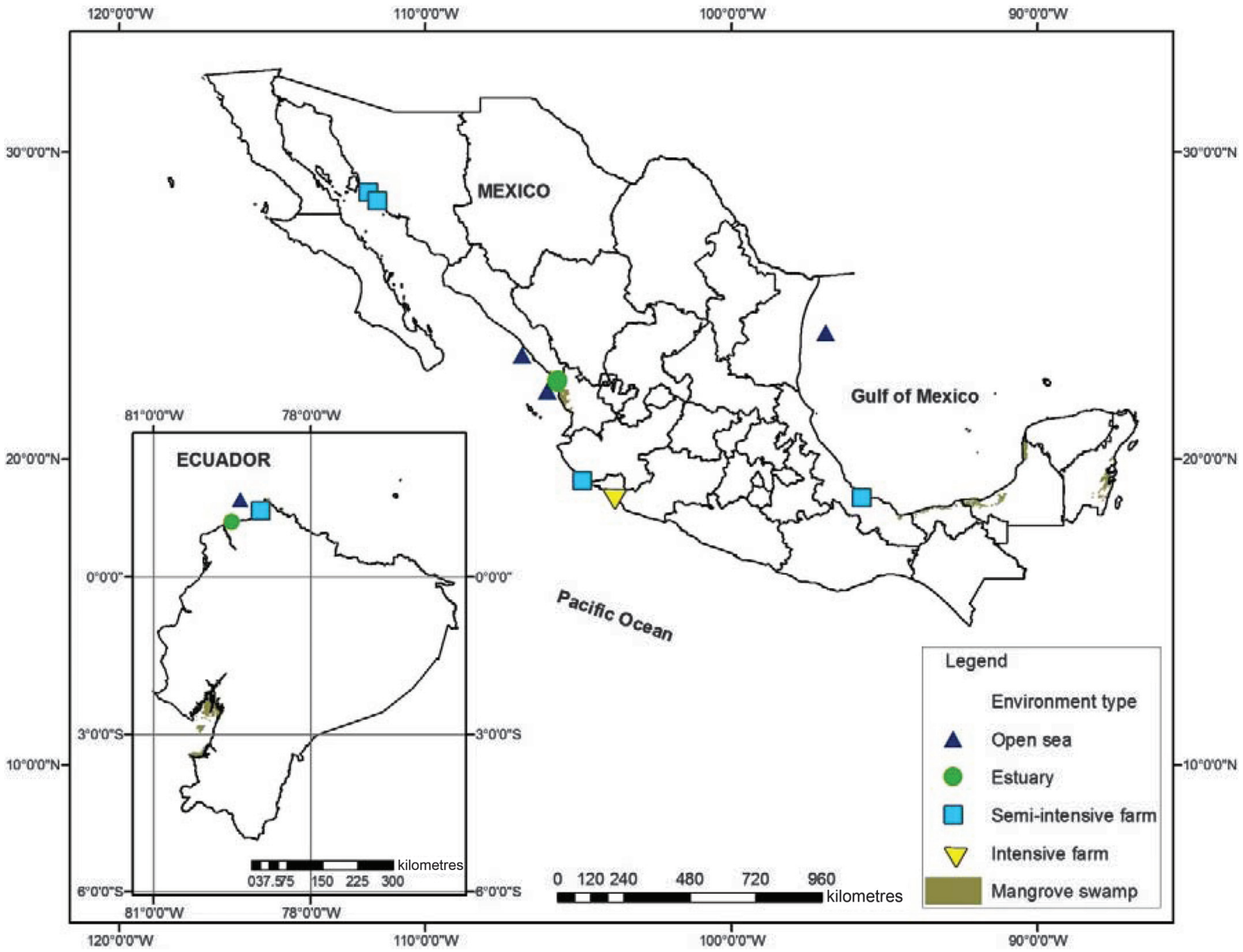

Following combustion, oxides were removed and helium-carried products flowed through water and $\mathrm{CO}_{2}$ traps (the latter for $\mathrm{N}$ analysis). $\mathrm{N}_{2}$ and $\mathrm{CO}_{2}$ were separated on a Carbosieve GC column before entering the IRMS. Repeated measurements of sample-interspersed internal calibration standards (nylon, bovine liver, and glutamic acid) indicated that instrument precision (standard deviation, SD) was $0.09 \%$ ofor $\delta^{15} \mathrm{~N}_{\mathrm{AIR}}$ and $0.13 \%$ 。 for $\delta^{13} \mathrm{C}_{\mathrm{VPDB}}$ values. Enriched L-glutamic acid (USGS-41, $\delta^{15} \mathrm{~N}_{\mathrm{AIR}}=47.60 \%$, $\delta^{13} \mathrm{C}_{\mathrm{VPDB}}=37.62 \%$ ) was used as international standard to calibrate internal standards. $\delta^{13} \mathrm{C}$ values for international standards are expressed with respect to the NBS19-LSVEC scale (USGS 2014). Isotopic values of samples are expressed in delta notation $(\delta)$, which is defined as per mil (\%o) deviations from the $\delta^{15} \mathrm{~N}$ and $\delta^{13} \mathrm{C}$ values of the isotopic standard reference materials (atmospheric nitrogen and Viena Pee Dee Belemnite (VPDB), respectively).

\section{Statistical analysis}

The isotopic signatures of the different shrimp samples were grouped according to environment and country. For each shrimp batch, linear regressions were used to examine relationships between $\delta^{13} \mathrm{C}_{\mathrm{VPDB}}$ and $\delta^{15} \mathrm{~N}_{\mathrm{AIR}}$ values and shrimp mass. The effect of location or environment on $\delta^{13} \mathrm{C}_{\mathrm{VPDB}}$ and $\delta^{15} \mathrm{~N}_{\mathrm{AIR}}$ values of muscle tissue was analyzed by one-way ANOVA after normal distribution and data homoscedasticity was verified. Tukey pairwise comparisons were used to detect values differing significantly at a level of significance of $p<0.01$. A canonical discriminant analysis (CDA) was performed to determine the classification power of the variables $\delta^{13} \mathrm{C}_{\mathrm{VPDB}}$ and $\delta^{15} \mathrm{~N}_{\mathrm{AIR}}$ to categorize shrimp samples collected from the different environments. The CDA standardizes values after applying discriminant functions and provides an indicator of how well the grouped variables are separated. CDA was applied using data from individual countries and isotopes and also considering both isotopic values for the three sampled environments, and finally CDA was run only with data from farmed and open ocean shrimp. Wilk's lambda indicated the magnitude at which variables $\delta^{13} \mathrm{C}_{\mathrm{VPDB}}$ and $\delta^{15} \mathrm{~N}_{\mathrm{AIR}}$ contributed in discriminating between groups (environment or production method). All tests were conducted using SPSS 17.0 software (SPSS Inc.).

\section{Results}

\section{Isotopic variability in shrimp samples}

The isotopic variability in shrimp muscle tissue samples was different among groups representing different environments (Figs. $2 a, 2 b$, and $3 a$ ). In general, $\delta^{13} C_{\mathrm{VPDB}}$ values showed higher variability than $\delta^{15} \mathrm{~N}_{\text {AIR }}$ values. Farmed animals showed lower 
Table 1. Type of environment, sampled locations, and mass range (g) of shrimps collected to authenticate production method by means of dual stable isotope analysis.

\begin{tabular}{|c|c|c|}
\hline Country and environment & Location & $\begin{array}{l}\text { Mass } \\
\text { range (g) }\end{array}$ \\
\hline \multicolumn{3}{|l|}{ Ecuador } \\
\hline Open sea FAO fishing area 87 & Pacific Ocean & $49-91$ \\
\hline Semi-intensive farm & La Tola, Esmeraldas & $15-21$ \\
\hline Estuary & La Tola, Esmeraldas & $4-8$ \\
\hline \multicolumn{3}{|l|}{ Mexico } \\
\hline $\begin{array}{l}\text { Open sea FAO fishing area } 77 \\
\text { (two locations) }\end{array}$ & Pacific Ocean & $\begin{array}{l}43-61 \\
18-30\end{array}$ \\
\hline Open sea FAO fishing area 31 & Gulf of Mexico & $36-60$ \\
\hline Semi-intensive farm & Tenacatita, Jalisco & $2-4$ \\
\hline Semi-intensive farm & Bahía de Kino, Sonora & $17-26$ \\
\hline $\begin{array}{l}\text { Semi-intensive farm } \\
\text { (five ponds sampled) }\end{array}$ & San Rafael, Sonora & $5-16$ \\
\hline Semi-intensive farm & Alvarado,Veracruz & $6-12$ \\
\hline $\begin{array}{l}\text { Low-salinity, intensively } \\
\text { managed farm }\end{array}$ & Tecuanillo, Colima & 9-14 \\
\hline \multirow{2}{*}{$\begin{array}{l}\text { Estuarine system } \\
\text { (three locations) }\end{array}$} & $\begin{array}{l}\text { Marismas Nacionales, } \\
\text { Sinaloa }\end{array}$ & $\begin{array}{l}2-8 \\
6-11\end{array}$ \\
\hline & & $5-12$ \\
\hline
\end{tabular}

nitrogen isotopic variability than wild organisms, although two batches of farmed shrimp presented high $\delta^{13} C_{\mathrm{VPDB}}$ variability. The latter observation was comparable to $\delta^{13} \mathrm{C}_{\mathrm{VPDB}}$ variability observed in animals sampled in estuaries (Table 2). Two batches of shrimp caught in open sea also presented a high variability in $\delta^{13} \mathrm{C}_{\mathrm{VPDB}}$ values, while $\delta^{15} \mathrm{~N}_{\mathrm{AIR}}$ values were narrower.

\section{Carbon and nitrogen isotope values in wild and farmed shrimps}

The distribution pattern of isotopic values was very similar for animals sampled in Ecuador and Mexico (Figs. $2 a$ and $2 b$; Table 2). Shrimp size was not significantly correlated to carbon or nitrogen stable isotope values in any of the batches $\left(R^{2}\right.$ ranged from 0.07 to 0.16). The higher correlation values between $\delta^{15} \mathrm{~N}_{\mathrm{AIR}}$ values and size were observed in shrimps caught in open sea. Overall isotopic values in sampled animals ranged from $-21.96 \%$ o to $-14.93 \%$ o for $\delta^{13} \mathrm{C}_{\mathrm{VPDB}}$ values and from $2.89 \%$ o to $16.79 \%$ for $\delta^{15} \mathrm{~N}_{\mathrm{AIR}}$ values. Mean $\delta^{13} \mathrm{C}_{\mathrm{VPDB}}$ and $\delta^{15} \mathrm{~N}_{\mathrm{AIR}}$ values in animals extracted from open sea in both countries were $-16.99 \%$ and $11.57 \%$, respectively. Such values were significantly different $(p<0.001)$ to $\delta^{13} C_{\text {VPDB }}$ and $\delta^{15} \mathrm{~N}_{\mathrm{AIR}}$ values measured in shrimps collected in estuaries $(-18.46 \%$ ond $5.38 \%$, respectively). Isotopic signatures of shrimps caught in open sea were also significantly different to $\delta^{13} C_{V P D B}$ and $\delta^{15} \mathrm{~N}_{\text {AIR }}$ values measured in farmed animals in both countries $(-19.72 \%$ ond $7.85 \%$, respectively). In general, shrimp collected in open sea were, on average, isotopically enriched by $3.28 \%$ of $\delta^{13} C_{\text {VPDB }}$ and by $4.11 \%$ ofor $\delta^{15} \mathrm{~N}_{\text {AIR }}$ when compared with mean isotopic values observed in farmed animals. Figure $3 a$ summarizes the mean isotopic values of shrimp batches collected in the three different environments in both countries.

\section{Discriminant analysis and classification of origin of shrimp samples}

The CDA individually applied to countries and isotopic values indicated that $\delta^{15} \mathrm{~N}_{\mathrm{AIR}}$ values were more reliable classification parameters, as $84 \%-93 \%$ of the cross-validated groups were correctly classified (Table 3 ). In contrast, $\delta^{13} \mathrm{C}_{\mathrm{VPDB}}$ values classified less shrimp in their respective environments (74\%-76\%). However, using both isotopic values of shrimps as discriminant factors, results from CDA indicated a clear separation between semi-intensively farmed animals and shrimp caught on the open sea in Ecuador and Mexico (Fig. 3b). When the CDA was applied to only classify farmed shrimp and wild-caught shrimp (industrial fishing), 99\% of
Table 2. Carbon and nitrogen isotope values of farmed and wildcaught Pacific white shrimp (L. vannamei) collected in Mexico and Ecuador (mean $\pm \mathrm{SD}$ ).

\begin{tabular}{lllr}
\hline Environment & $\delta^{13} \mathrm{C}_{\mathrm{VPDB}}(\%)$ & $\delta^{15} \mathrm{~N}_{\mathrm{AIR}}(\%)$ & $n$ \\
\hline Ecuador & & & \\
Open sea & $-16.60 \pm 0.90 \mathrm{c}$ & $9.76 \pm 0.55 \mathrm{c}$ & 21 \\
Estuary & $-18.32 \pm 1.02 \mathrm{~b}$ & $4.25 \pm 0.84 \mathrm{a}$ & 15 \\
Semi-intensively farmed & $-19.86 \pm 0.84 \mathrm{a}$ & $6.02 \pm 0.17 \mathrm{~b}$ & 10 \\
Mexico & & & \\
Open sea & $-17.14 \pm 0.44 \mathrm{~d}$ & $12.19 \pm 2.24 \mathrm{c}$ & 61 \\
Estuary & & & \\
Semi-intensively farmed & $-18.59 \pm 1.22 \mathrm{c}$ & $5.88 \pm 1.37 \mathrm{a}$ & 30 \\
Intensively farmed & $-21.69 \pm 0.92 \mathrm{~b}$ & $8.32 \pm 0.81 \mathrm{~b}$ & 45 \\
\hline
\end{tabular}

Note: Different letters indicate significant differences for that particular country and column at a level of significance of $p<0.01$. Statistical parameters for environment comparison are as follows:

Ecuador $\delta^{13} C_{\mathrm{VPDB}}$ values, $F_{[2,43]}=43.9$, mean standard error $(\mathrm{MSE})=0.86$, $p<0.001$.

Ecuador $\delta^{15} \mathrm{~N}_{\mathrm{AIR}}$ values, $\mathrm{F}_{[2,43]}=370.7$, MSE $=0.37, p<0.001$.

Mexico $\delta^{13} \mathrm{C}_{\mathrm{VPDB}}$ values, $\mathrm{F}_{[3,140]}=147.0$, MSE $=0.55, p<0.001$.

Mexico $\delta^{15} \mathrm{~N}_{\text {AIR }}$ values, $\mathrm{F}_{[3,140]}=108.7, \mathrm{MSE}=2.78, p<0.001$.

${ }^{a}$ Mean values for three estuarine locations.

the shrimp were correctly classified. $100 \%$ of the shrimps caught at open sea $(n=82)$ were correctly classified, while only one farmed individual was classified as wild (Table 4). Wilk's lambda values were small ( 0.19 for $\delta^{13} C_{\text {VPDB }}$ values $\left(F_{[1,135]}=548, p<0.001\right)$ and 0.51 for $\delta^{15} \mathrm{~N}_{\mathrm{AIR}}$ values $\left.\left(F_{[1,135]}=130, p<0.001\right)\right)$, thus indicating the significance of the independent variables to the discriminant function. After incorporating estuary shrimps into the CDA, results indicated that $87 \%$ of all cases were correctly classified when including the three environments in the analysis (Table 4). $100 \%$ of the shrimps caught at open sea $(n=82)$ were correctly classified, while 5 out of 50 farmed shrimp were misclassified as collected from estuaries. Eighteen out of 45 individuals sampled from estuaries were classified as farmed. The latter misclassifications were accounted to the isotopic overlap of both $\delta^{13} \mathrm{C}_{\mathrm{VPDB}}$ and $\delta^{15} \mathrm{~N}_{\mathrm{AIR}}$ values in farmed animals and shrimps collected in estuaries (Fig. 3a).

\section{Discussion}

\section{Isotopic variability in shrimp samples from farms and wild} environments

The use of untreated muscle tissue for the isotopic analysis of crustaceans has been previously recommended (Stenroth et al. 2006), as it can be obtained through straightforward sampling procedures, and the carbon and nitrogen isotope values of abdominal muscle tissue represent well the isotopic values of whole shrimp bodies (Gamboa-Delgado et al. 2011). The variability in $\delta^{13} C_{\mathrm{VPDB}}$ and $\delta^{15} \mathrm{~N}_{\mathrm{AIR}}$ values in individuals belonging to wild environments was higher than that observed for farmed organisms. The wider range of isotopic values reflects the higher availability of trophic items available for wild shrimps in comparison with farmed animals.

The isotopic values of animal consumers are mainly affected by growth and metabolic turnover. In larval and juvenile organisms, isotopic changes are mainly due to growth; hence, the ingestion and assimilation of nutrients have a direct and fast influence on the isotopic composition of growing tissue. Penaeid shrimps are highly mobile organisms and change their feeding habits as a function of the available trophic items in their feeding niches. Despite these fast trophic changes, previous studies conducted in laboratory have demonstrated that shrimps rapidly achieve isotopic equilibrium with their diets and reflect the isotopic value of the available preys or feeding items over a period of 2-3 weeks (Fry and Arnold 1982; Gamboa-Delgado et al. 2011). In the present study, the observed poor correlation ( $R^{2}$ ranged from 0.07 to 0.16 ) between individual shrimp mass and isotopic values of samples of 
Fig. 2. Carbon and nitrogen isotope values in muscle tissue of shrimps collected from the open sea, estuaries, and semi-intensively managed shrimp farms in (a) Ecuador and (b) Mexico. Inverted triangles correspond to organisms sampled at a low salinity, intensively managed shrimp farm.
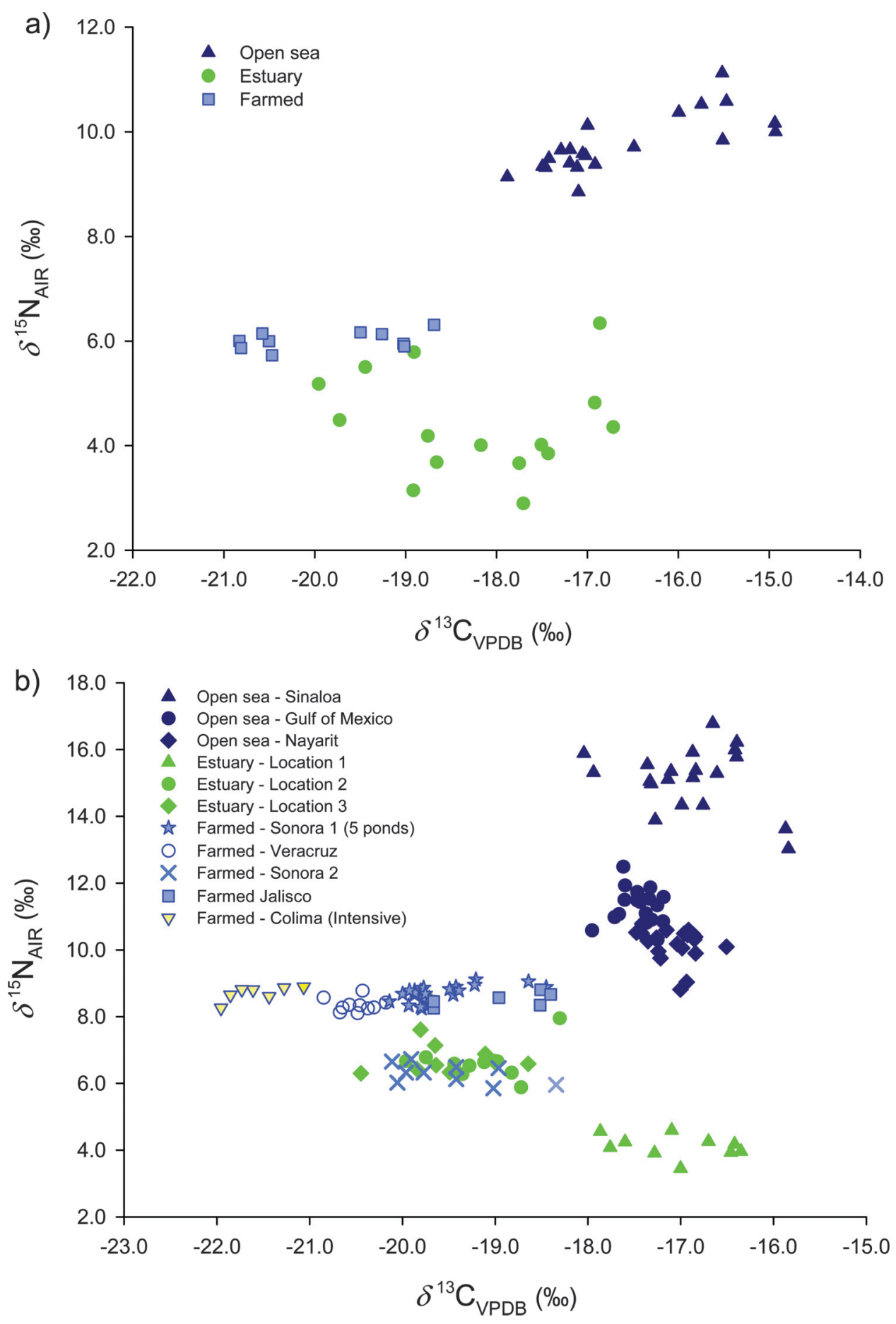

the same wild origin indicate that animals having different sizes were probably feeding on similar trophic elements.

Under farming conditions, shrimp derive their nutrients from the pond's natural productivity and from the formulated feeds. It has been demonstrated that shrimp exert a strong foraging pressure on the natural biota, and therefore nutrients from the artificial feeds are incorporated at even higher proportions towards the last weeks of the farming period (Cam et al. 1991). Differences in the availability of dietary elements can partially explain the higher isotopic variability $\left(\delta^{13} \mathrm{C}_{\mathrm{VPDB}}\right.$ and $\left.\delta^{15} \mathrm{~N}_{\mathrm{AIR}}\right)$ observed in wild shrimps as compared with farmed shrimps. In studies conducted on fish, Bell et al. (2007) reported higher variability of $\delta^{13} C_{V P D B}$ values in lipids of European seabass (D. labrax), while Busetto et al. (2008) reported higher isotopic variability (two- to sixfold) in muscle tissue of wild turbot (Scophthalmus maximus, cited as Psetta maxima) as compared with farmed animals. The lower isotopic variability observed in farmed animals can be attributed to the constant availability of formulated feed for these individuals. Although the isotopic values of formulated feed also change because of formulation and leaching of nutrients, values are still more constant than the isotopic values of the natural biota available to farmed shrimps, which presents natural ecological successions (Gamboa-Delgado 2014). 
Fig. 3. (a) Carbon and nitrogen stable isotope values (means \pm SD) of Mexican and Ecuadorian shrimps collected in the open sea, estuaries, and semi-intensive farms. The inverted triangle symbol corresponds to shrimps collected at a low salinity, intensively managed shrimp farm in Mexico. (b) Discriminant analysis for authentication of shrimp production method based on carbon and nitrogen stable isotope values in muscle tissue of shrimps collected from the open sea, estuaries, and semi-intensively managed shrimp farms. Centroids represent means of standardized group values.
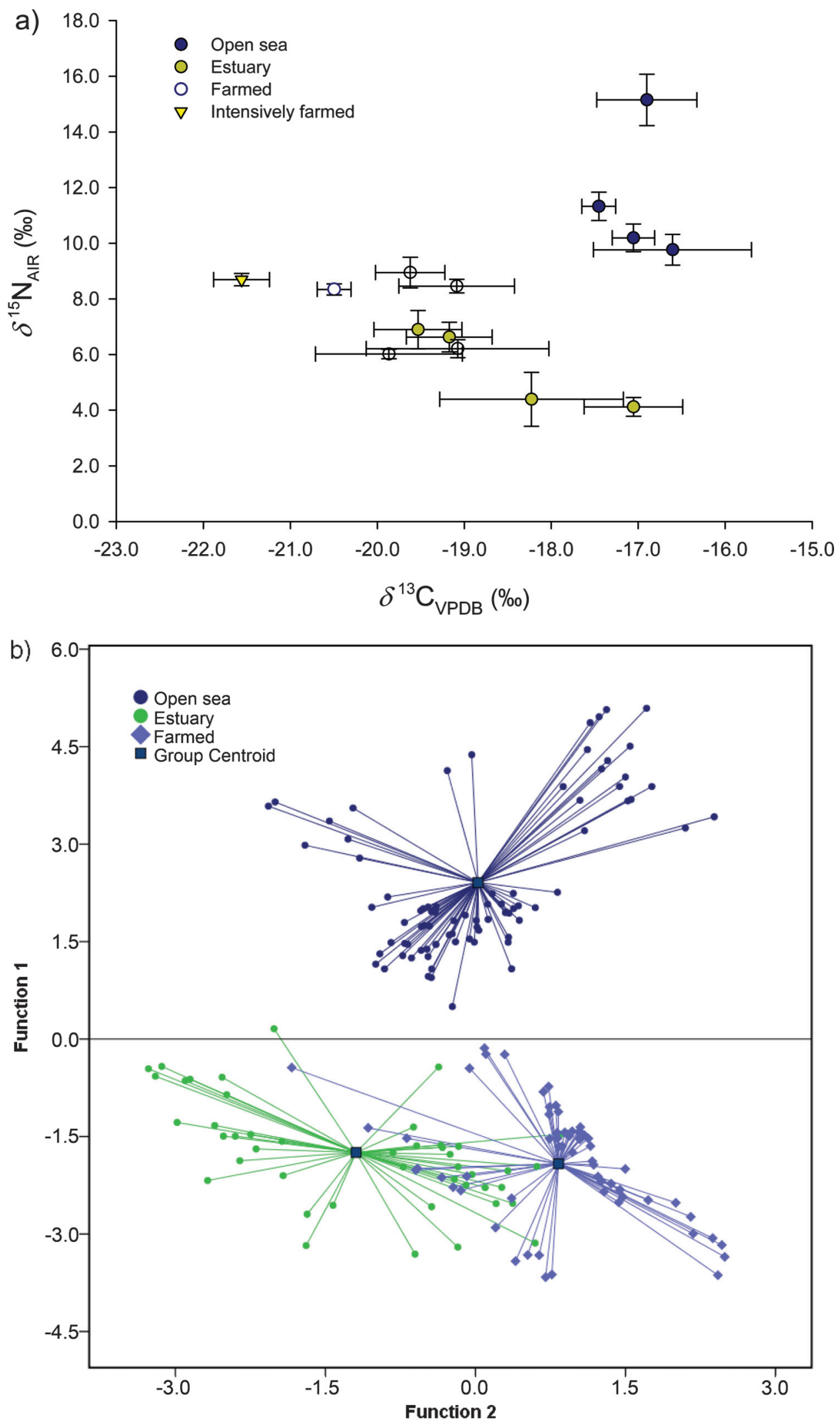

$\downarrow$ Published by NRC Research Press 
Table 3. Environment classification of cross-validated results of muscle tissue samples of shrimps collected in Ecuador and Mexico on the basis of the discriminant functions calculated from carbon and nitrogen stable isotope values.

Predicted environment

classification

Country, isotope Environment Open sea Estuary Farmed Total

Ecuador, carbon $^{a}$

Cross-validated

Cross-validated

Open sea

Estuary

Farmed

Estuary

Farmed

20
4
0
95.2
26.7
0

1
8
4
4.8
53.3
40.0

0

3

6

0

20.0

60.0

21

15

10

100

100

Ecuador, nitrogen ${ }^{b}$

$\begin{array}{clllll}\text { Cross-validated } & \text { Open sea } & 21 & 0 & 0 & 21 \\ \text { count } & \text { Estuary } & 0 & 12 & 3 & 15 \\ & \text { Farmed } & 0 & 0 & 10 & 10 \\ \text { Cross-validated } & \text { Open sea } & 100 & 0 & 0 & 100 \\ \text { percentage } & \text { Estuary } & 0 & 80.0 & 20.0 & 100 \\ & \text { Farmed } & 0 & 0 & 100 & 100\end{array}$

Mexico, carbon $^{c}$

$\begin{array}{clllll}\text { Cross-validated } & \text { Open sea } & 61 & 0 & 0 & 61 \\ \text { count } & \text { Estuary } & 10 & 4 & 16 & 30 \\ & \text { Farmed } & 1 & 5 & 39 & 45 \\ \text { Cross-validated } & \text { Open sea } & 100 & 0 & 0 & 100 \\ \text { percentage } & \text { Estuary } & 33.3 & 13.3 & 53.3 & 100 \\ & \text { Farmed } & 2.2 & 11.1 & 86.7 & 100\end{array}$

Mexico, nitrogen ${ }^{d}$

$\begin{array}{clllll}\text { Cross-validated } & \text { Open sea } & 56 & 0 & 5 & 61 \\ \text { count } & \text { Estuary } & 0 & 18 & 12 & 30 \\ & \text { Farmed } & 0 & 5 & 40 & 45 \\ \text { Cross-validated } & \text { Open sea } & 91.8 & 0 & 8.2 & 100 \\ \text { percentage } & \text { Estuary } & 0 & 60.0 & 40.0 & 100 \\ & \text { Farmed } & 0 & 11.1 & 88.9 & 100\end{array}$

Note: Cross-validation is done only for those cases in the analysis. In crossvalidation, each case is classified by the functions derived from all cases other than that case. Isotopic values of intensively farmed shrimp were not included in the analysis. Percentages of cross-validated grouped cases correctly classified are shown below.

a73.9\%. Wilk's lambda $=0.32, \mathrm{~F}_{[2,42]}=43.95, p<0.001$.

b93.5\%. Wilk's lambda $=0.05, F_{[2,42]}=370.70, p<0.001$.

${ }^{c 76.5 \%}$. Wilk's lambda $=0.30, \mathrm{~F}_{[2,133]}=150.99, p<0.001$.

${ }^{d} 83.8 \%$. Wilk's lambda $=0.30, F_{[2,133]}=155.49, p<0.001$.

\section{Isotopic enrichment and depletion in shrimp samples}

The isotopic enrichment has been defined as a process by which the relative abundance of the isotopes of a given element is altered, thus producing a new isotopic ratio that has been enriched in one particular isotope. Animal consumers have a tendency to accumulate the heavier isotopes, and this effect produces an isotopic difference between diet and consumer (isotopic discrimination factor). In field studies, the nitrogen isotope value of a wild animal can indicate its trophic position, but under controlled farming conditions, the flows of nutrients (and isotopes) are significantly modified. These changes are caused by the presence of different trophic elements in the available pond biota, the use of isotopically depleted ingredients in the supplied formulated diets, and the recycling of nutrients (diet detritus, shrimp moults, and feces) occurring in the relatively closed systems. Dietary ingredients such as terrestrial plant meals and rendered products imprint different isotopic values to farmed organisms (usually lower). The isotopic enrichment (in relation to farmed animals) observed in shrimp collected on the open sea $\left(\delta^{13} \mathrm{C}_{\mathrm{VPDB}}=+3.28 \%\right.$ o and $\delta^{15} \mathrm{~N}_{\mathrm{AIR}}=+4.11 \%$ 。) reflects the higher trophic niche they occupy in the natural ecosystems. On the other hand, the isotopic depletion in tissues of farmed animals is also evident in the present study, and it can be partially
Table 4. Classification of cross-validated results of muscle tissue samples of shrimps collected in different environments in Ecuador and Mexico on the basis of the discriminant functions calculated from carbon and nitrogen stable isotope values.

\begin{tabular}{clllll}
\hline & & \multicolumn{3}{l}{$\begin{array}{l}\text { Predicted environment } \\
\text { classification }\end{array}$} \\
\cline { 3 - 6 } & Environment & Open sea & Estuary & Farmed & Total \\
\hline Not including estuary & & & & & \\
Cross-validated & Open sea & 82 & NA & 0 & 82 \\
count & Farmed & 1 & NA & 54 & 55 \\
Cross-validated & Open sea & 100 & NA & 0 & 100 \\
percentage & Farmed & 1.8 & NA & 98.2 & 100 \\
Including estuary & & & & & \\
Cross-validated & Open sea & 82 & 0 & 0 & 82 \\
count & Estuary & 0 & 27 & 18 & 45 \\
Cross-validated & Farmed & 0 & 5 & 50 & 55 \\
percentage & Open sea & 100 & 0 & 0 & 100 \\
& Estuary & 0 & 60.0 & 40.0 & 100 \\
& Farmed & 0 & 9.1 & 90.9 & 100 \\
\hline
\end{tabular}

Note: Cross-validation is done only for those cases in the analysis. In crossvalidation, each case is classified by the functions derived from all cases other than that case. NA, not applicable.

$a 99.3 \%$ of cases were correctly classified when CDA was applied to farmed and open sea shrimp. $\delta^{13} C_{\mathrm{VPDB}}$ values, Wilk's lambda $=0.19, \mathrm{~F}_{[1,135]}=548.40, p<0.001$. $\delta^{15} \mathrm{~N}_{\mathrm{AIR}}$ values, Wilk's lambda $=0.50, F_{[1,135]}=130.39, p<0.001$.

${ }^{b} 87.4 \%$ of cross-validated grouped cases were correctly classified when CDA was applied to farmed, estuary, and open sea shrimp. $\delta^{13} C_{\text {VPDB }}$ values, Wilk's lambda $=0.32, F_{[2,179]}=185.28, p<0.001 . \delta^{15} \mathrm{~N}_{\mathrm{AIR}}$ values, Wilk's lambda $=0.31$, $F_{[2,179]}=191.59, p<0.001$.

attributed to the use of formulated feeds. To increase feed stability and replace a proportion of expensive animal-derived proteins, aquaculture feeds are frequently formulated with varying dietary levels of plant meals. These plant meals are mostly derived from terrestrial plants having C3 photosynthesis and are less enriched in ${ }^{13} \mathrm{C}\left(\right.$ mean $\delta{ }^{13} \mathrm{C}_{\mathrm{VPDB}}=-29 \%$ ) as compared with $\mathrm{C} 4$ plants (mean $\delta^{13} \mathrm{C}_{\mathrm{VPDB}}=-13 \%$ ) (Ehleringer and Cerling 2001; Moreno-Rojas et al. 2007). C3 plants are also less enriched when compared with several marine-derived ingredients such as fish meal $\left(\delta^{13} C_{\text {VPDB }}=-17 \%\right.$ o). For example, some shrimp feeds used in Mexico have $\delta^{13} \mathrm{C}_{\mathrm{VPDB}}$ values ranging from $-23.6 \%$ o to $-22.3 \%$ ond $\delta^{15} \mathrm{~N}_{\text {AIR }}$ values ranging from $5.8 \%$ o to $9.7 \%$. The $\delta^{13} \mathrm{C}_{\mathrm{VPDB}}$ values of feed are thus transferred to the farmed organisms, hence causing contrasting $\delta^{13} \mathrm{C}_{\mathrm{VPDB}}$ values (more isotopically depleted) as compared with those observed in tissue of wild animals.

\section{Carbon and nitrogen isotope values in shrimps from different environments}

Juvenile and adult shrimp are highly mobile organisms and they occupy different ecological niches and varying trophic levels during their life cycle. Stomach content analysis and relatively enriched somatic isotopic values indicate that adult shrimp shift their feeding habits from omnivory to more pronounced carnivorous habits as shrimps migrate from the estuarine environments to the open sea (Schwamborn and Criales 2000). In a study conducted on open sea shrimp, Moncreiff and Sullivan (2001) reported isotopically enriched $\delta^{13} \mathrm{C}_{\mathrm{VPDB}}$ and $\delta^{15} \mathrm{~N}_{\mathrm{AIR}}$ values for shrimp species caught in the Gulf of Mexico (Farfantepenaeus aztecus: $\delta^{13} \mathrm{C}_{\mathrm{VPDB}}=-17.7 \%$ ond $\delta^{15} \mathrm{~N}_{\mathrm{AIR}}=11.0 \%$; Farfantepenaeus duorarum: $\delta^{13} \mathrm{C}_{\mathrm{VPDB}}=-16.5 \%$ and $\delta^{15} \mathrm{~N}_{\mathrm{AIR}}=11.2 \%$; Litopenaeus setiferus: $\delta^{13} \mathrm{C}_{\mathrm{VPDB}}=$ $-19.6 \%$ and $\delta^{15} \mathrm{~N}_{\mathrm{AIR}}=11.4 \%$ ). These values are very similar to isotopic values measured in the present study in shrimps caught in the Pacific and Atlantic oceans. In contrast with shrimps in adult stage living in the open sea, postlarval shrimps in estuaries derive high proportions of their dietary carbon and nitrogen from epiphytes and benthic microalgae (Gleason 1986). Results from the 
present study indicate that mean isotopic values of shrimps collected in estuaries in Mexico and Ecuador were very consistent $\left(\delta^{13} \mathrm{C}_{\mathrm{VPDB}}=-19.87 \%\right.$ o to $-18.59 \%$ o and $\delta^{15} \mathrm{~N}_{\mathrm{AIR}}=5.88 \%$ o to $6.02 \%$ 。). Estuary shrimps collected in Mexico represented three different sampling locations in a coastal lagoon complex. The relatively depleted isotopic values measured are also characteristic of the feeding items available to shrimps in estuarine habitats, mud flats, and sand flats of areas surrounded by mangrove forests (Macia 2004; Primavera 1996). Chong et al. (2001) applied isotopic techniques to estimate the contribution of mangrove detritus to the growth of shrimp in estuaries, which was estimated to be as high as $84 \%$. More recently, Gatune et al. (2012) demonstrated that mangrove detritus and the biofilm growing on it are important dietary sources to shrimps. The isotopic values of the latter sources are very different to the isotopic signatures of the trophic sources available to animals in the open sea. Moreover, Abrantes and Sheaves (2010) reported that estuary-dwelling animals obtain a significant proportion of nutrients from allochthonous sources such as terrestrial-derived feeding items (also isotopically distinct) that are transported to the estuaries by rivers. Farmed shrimp derive their nutrients from the pond's natural productivity and from the supplied formulated feeds. Many shrimp farms are located near estuaries and mangrove areas and actually pump seawater from these systems, hence explaining some isotopic similarities in the natural biota representative of both environments. In Mexico, most shrimp farms apply protocols to stimulate the natural production by using inorganic fertilizers. The inorganic fertilizers are isotopically depleted and might also imprint lower isotopic signatures to the primary producers in shrimp ponds as compared with those in the natural ecosystems.

Shrimps extracted from the natural environment (estuaries and open ocean) showed higher isotopic variability, and their mean $\delta^{13} \mathrm{C}_{\mathrm{VPDB}}$ and $\delta^{15} \mathrm{~N}_{\mathrm{AIR}}$ values were statistically different than those of farmed animals. In both countries, $\delta^{15} \mathrm{~N}_{\text {AIR }}$ values were more accurate than $\delta^{13} \mathrm{C}_{\mathrm{VPDB}}$ values in differentiating the environment shrimp were collected from. The latter observation highlights the fact that $\delta^{15} \mathrm{~N}_{\mathrm{AIR}}$ values of wild shrimp (open sea) represent well their higher trophic position when compared with estuary and farmed shrimp. However, when CDA analysis incorporated both isotopic values as discriminant factors and was applied only to farmed and open sea shrimp, $\delta^{13} C_{\mathrm{VPDB}}$ values offered higher discriminating power between these two groups. In contrast, when estuary shrimps were incorporated into the CDA, the classification accuracy decreased because of the overlap of isotopic values between shrimps collected in estuaries and semi-intensively farmed animals. Every semi-intensive shrimp pond has its own specific characteristics, and the natural communities developing in it can drastically vary; however, as shrimp farming systems intensify, higher proportions of dietary nitrogen and carbon are derived from the formulated feeds. This is due to the cumulative effect of the grazing activity occurring at higher animals densities, thus counteracting the establishment of natural biota populations. Such changes in the availability of trophic elements for shrimp imply that $\delta^{13} \mathrm{C}_{\mathrm{VPDB}}$ and $\delta^{15} \mathrm{~N}_{\mathrm{AIR}}$ values in animals reared under intensive and hyperintensive conditions (recirculating aquaculture systems) will reflect the isotopic values of formulated feed at a higher magnitude than semi-intensively farmed animals, thus positioning these animals even farther from the isotopic values of animals caught on the open sea. This effect is adverted by the ${ }^{13} \mathrm{C}$-depleted values of shrimps $\left(\delta^{13} \mathrm{C}_{\mathrm{VPDB}}=-21.6 \%\right.$ ) sampled at the farm operating under intensive stocking conditions and allows forecasting a more sensitive discrimination of farmed and wild shrimps when applying isotopic techniques. The isotopic values of intensively farmed shrimps strongly reflected the $\delta^{13} \mathrm{C}_{\mathrm{VPDB}}$ values of the supplied commercial feed $(-22.3 \%)$, hence widening the difference when compared with animals caught on the open sea. The application of isotopic analysis has clearly allowed discriminating wild from farmed individuals of several species of marine fish
(Bell et al. 2007; Dempson and Power 2004; Moreno-Rojas et al. 2007; Serrano et al. 2007), and to our knowledge, this is the first study applying isotopic methodologies to discriminate the production method of a crustacean species.

\section{Future studies}

The increasing availability of commercial analytical services offering affordable isotope analysis forecasts further studies on the traceability of different marine products. Penaeid shrimps are characterized by complex life cycles and dramatic trophic changes. A limited amount of information is currently available on the diet-elicited isotopic changes occurring during larval, postlarval, juvenile, and adult shrimp stages. Future studies will indicate how different isotopic values correlate with feeding habits and shrimp mass and thus will assist in better defining isotopic signatures characteristic of wild and farmed shrimps.

This preliminary study demonstrated that samples from farmed shrimp or wild-caught in the open sea can be clearly identified by measuring the isotopic values of carbon and nitrogen in shrimp abdominal muscle tissue. Additional sampling will assist in defining confidence intervals for the isotopic signatures of fisheriesderived shrimp and semi-intensively farmed shrimp. Improvements to the present methodology might aid to implement a verification scheme to support shrimp traceability and to detect deliberate mislabeling of farmed and wild animals. As the overlap of isotopic values can occur in groups from different origins, the application of additional techniques such as the analysis of the isotopic ratio of other elements might allow distinguishing shrimp batches having closely grouped carbon and nitrogen isotopic signatures. In the present study, nitrogen isotope values were reliable indicators of trophic position, and in conjunction with carbon isotope values a further separation was observed between groups of shrimp caught in the open sea and farmed shrimp.

\section{Acknowledgements}

The authors acknowledge the Instituto Geográfico Militar Ecuatoriano and the Instituto Nacional de Estadística y Geografía (Mexico) for providing cartographic information. Melva Godina Herrera is acknowledged for her assistance in the geographic information. We are thankful to three anonymous reviewers whose comments and suggestions helped to improve and clarify this manuscript.

\section{References}

Abrantes, K.G., and Sheaves, M. 2010. Importance of freshwater flow in terrestrial-aquatic energetic connectivity in intermittently connected estuaries of tropical Australia. Mar. Biol. 157(9): 2071-2086. doi:10.1007/s00227-010-1475-8.

Arechavala-Lopez, P., Fernandez-Jover, D., Black, K.D., Ladoukakis, E., Bayle-Sempere, J.T., Sanchez-Jerez, P., and Dempster, T. 2013. Differentiating the wild or farmed origin of Mediterranean fish: a review of tools for sea bream and sea bass. Rev. Aquacult. 5(3): 137-157. doi:10.1111/raq.12006.

Bell, J., Preston, T., Bron, J., Henderson, R.J., Strachan, F., Cooper, K., and Morrison, D.J. 2007. Discrimination of wild and cultured European sea bass (Dicentrarchus labrax) using chemical and isotopic analyses. J. Agric. Food Chem. 55(15): 5934-5941. doi:10.1021/jf0704561.

Bodin, N., Le Loc'h, F., and Hily, C. 2007. Effect of lipid removal on carbon and nitrogen stable isotope ratios in crustacean tissues. J. Exp. Mar. Biol. Ecol. 341(2): 168-175. doi:10.1016/j.jembe.2006.09.008.

Busetto, M.L., Moretti, V.M., Moreno-Rojas, J.M., Caprino, F., Giani, I., Malandra, R., Bellagamba, F., and Guillou, C. 2008. Authentication of farmed and wild turbot (Psetta maxima) by fatty acid and isotopic analyses combined with chemometrics. J. Agric. Food Chem. 56(8): 2742-2750. doi:10.1021/ jf0734267.

Cam, D., Rollet, P.-E., Mariotti, A., and Guillaume, J. 1991. The relative contribution of natural productivity and formulated food in the nutrition of Penaeus japonicus reared in semi-intensive conditions. Aquat. Living Resour. 4(3): 175180. [In French.] doi:10.1051/alr:1991019.

Chong, V.C., Low, C.B., and Ichikawa, T. 2001. Contribution of mangrove detritus to juvenile prawn nutrition: a dual stable isotope study in a Malaysian mangrove forest. Mar. Biol. 138(1): 77-86. doi:10.1007/s002270000434.

CNA. 2012. Exportaciones acumuladas de camarón [online]. Cámara Nacional de Acuacultura, Ecuador. Available from http://www.cna-ecuador.com/ estadisticas-cna/camaron [accessed 22 March 2013]. 
COFEMER. 2013. Dictamen final sobre el anteproyecto denominado Norma Oficial Mexicana NOM-047-PESC-2012 para la identificación del origen de camarones cultivados, de agua marinas y esteros, marismas y bahías [online]. Comisión Federal de Mejora Regulatoria. Available from http://207.248.177. 30/expediente/v99/_COFEME.13.0292.pdf [accessed 1 July 2013].

CONAPESCA. 2010. Anuario Estadístico de Acuacultura y Pesca [online]. Comisión Nacional de Acuacultura y Pesca, Mexico. Available from: http://www. conapesca.sagarpa.gob.mx/wb/cona/anuario2010 [accessed 17 January 2013].

CONAPESCA. 2012. Anuario Estadístico de Acuacultura y Pesca [online]. Comisión Nacional de Acuacultura y Pesca, México. Available from http://www. conapesca.sagarpa.gob.mx/wb/cona/cona_anuario_estadistico_de_pesca [accessed 30 June 2013].

Dempson, J.B., and Power, M. 2004. Use of stable isotopes to distinguish farmed from wild Atlantic salmon, Salmo salar. Ecol. Freshw. Fish, 13(3): 176-184. doi:10.1111/j.1600-0633.2004.00057.x.

EC. 2001. Commission Regulation (EC) No. 2065/2001 of 22 October 2001 laying down detailed rules for the application of Council Regulation (EC) No. 104/ 2000 as regards informing consumers about fishery and aquaculture products [online]. Official Journal of the European Communities, L278/6. Available from http://eur-lex.europa.eu/LexUriServ/LexUriServ.do?uri=OJ:L: 2001:278:0006:0008:EN:PDF [accessed 2 April 2013].

EC. 2002. Commission Regulation (EC) No. 178/2002 of 28 January2002 laying down the general principles and requirements of food law, establishing the European Food Safety Authority and laying down procedures in matters of food safety [online]. Official Journal of the European Communities, L31/24. Available from http://eur-lex.europa.eu/LexUriServ/LexUriServ.do?uri=OJ:L: 2002:031:0001:0024:EN:PDF [accessed 2 April 2013].

Ehleringer, J.R., and Cerling, T.E. 2001. C3 and C4 photosynthesis. In Encyclopedia of global environmental change. Vol. II. Edited by H.A. Mooney and J.G. Canadell. John Wiley and Sons, New York. pp. 186-190.

Felton, L.A., Shah, P.P., Sharp, Z., Atudorei, V., and Timmins, G.S. 2011. Stable isotope-labeled excipients for drug product identification and counterfeit detection. Drug Dev. Ind. Pharm. 37(1): 88-92. doi:10.3109/03639045.2010. 492397. PMID:20560792.

Fry, B., and Arnold, C. 1982. Rapid ${ }^{13} \mathrm{C} /{ }^{12} \mathrm{C}$ turnover during growth of brown shrimp (Penaeus aztecus). Oecologia, 54(2): 200-204. doi:10.1007/BF00378393.

Gamboa-Delgado, J. 2014. Nutritional role of natural productivity and formulated feed in semi-intensive shrimp farming as indicated by natural stable isotopes. Rev. Aquacult. 6(1): 36-47. doi:10.1111/raq.12023.

Gamboa-Delgado, J., Peña-Rodríguez, A., Ricque-Marie, D., and Cruz-Suárez, L.E. 2011. Assessment of nutrient allocation and metabolic turnover rate in Pacific white shrimp Litopenaeus vannamei co-fed live macroalgae Ulva clathrata and inert feed: dual stable isotope analysis. J. Shellfish Res. 30(3): 969-978. doi: 10.2983/035.030.0340

Gatune, C., Vanreusel, A., Cnudde, C., Ruwa, R., Bossier, P., and De Troch, M. 2012. Decomposing mangrove litter supports a microbial biofilm with potential nutritive value to penaeid shrimp post larvae. J. Exp. Mar. Biol. Ecol. 426-427: 28-38. doi:10.1016/j.jembe.2012.05.015.

Gleason, D.F. 1986. Utilization of salt marsh plants by postlarval brown shrimp: carbon assimilation rates and food preferences. Mar. Ecol. Prog. Ser. 31: 151-158. doi:10.3354/meps031151.

Jacquet, J.L., and Pauly, D. 2008. Trade secrets: renaming and mislabeling of seafood. Mar. Pol. 32(3): 309-318. doi:10.1016/j.marpol.2007.06.007.

Kropf, U., Golob, T., Nečemer, M., Kump, P., Korošec, M., Bertoncelj, J., and Ogrinc, N. 2010. Carbon and nitrogen natural stable isotopes in Slovene honey: adulteration and botanical and geographical aspects. J. Agr. Food Chem. 58(24): 12794-12803. doi:10.1021/jf102940s.

Macia, A. 2004. Primary carbon sources for juvenile penaeid shrimps in a mangrove-fringed bay of Inhaca Island, Mozambique: a dual carbon and nitrogen isotope analysis. Western Indian Ocean J. Mar. Sci. 3(2): 151-161. doi:10.4314/wiojms.v3i2.28458.
Martínez del Rio, C., and Wolf, B.O. 2005. Mass-balance models for animal isotopic ecology. In Physiological and ecological adaptations to feeding in vertebrates. Edited by J.M. Starck and T. Wang. Science Publishers, Enfield, N.H. pp. 141-174.

Minagawa, M., and Wada, E. 1984. Stepwise enrichment of $\delta^{15} \mathrm{~N}$ along food chains: further evidence and the relation between $\delta^{15} \mathrm{~N}$ and animal age. Geochim. Cosmochim. Acta, 48(5) 1135-1140. doi:10.1016/0016-7037(84)90204-7.

Moncreiff, C.A., and Sullivan, M.J. 2001. Trophic importance of epiphytic algae in subtropical seagrass beds: evidence from multiple stable isotope analyses. Mar. Ecol. Prog. Ser. 215: 93-106. doi:10.3354/meps215093.

Moreno-Rojas, J.M., Serra, F., Giani, I., Moretti, V.M., Reniero, F., and Guillou, C. 2007. The use of stable isotope ratio analyses to discriminate wild and farmed gilthead sea bream (Sparus aurata). Rapid Commun. Mass Sp. 21(2): 207-211. doi:10.1002/rcm.2836.

Moretti, V.M., Turchini, G.M., Bellagamba, F., and Caprino, F. 2003. Traceability issues in fishery and aquaculture products. Vet. Res. Commun. 27(1): 497505. doi:10.1023/B:VERC.0000014207.01900.5c. PMID:14535457.

NOAA. 2011. NOAA investigations into mislabeling seafood protects consumers and fishermen [online]. National Oceanic and Atmospheric Administration, Office of Law Enforcement. Available from http://www.noaanews.noaa.gov/ stories2011/20110204_seafoodmislabeling.html [accessed 2 May 2012].

Nunes, A.J.P., Gesteira, T.C.V., and Goddard, S. 1997. Food ingestion and assimilation by the Southern brown shrimp Penaeus subtilis under semi-intensive culture in NE Brazil. Aquaculture, 149(1-2): 121-136. doi:10.1016/S0044-8486 (96)01433-0.

Pérez-Farfante, I. 1988. Illustrated key to penaeoid shrimps of commerce in the Americas. NOAA Technical Report NMFS, Vol. 64. pp. 1-38.

Peterson, B.J., and Fry, B. 1987. Stable isotopes in ecosystem studies. Annu. Rev. Ecol. Syst. 18: 293-320. doi:10.1146/annurev.es.18.110187.001453.

Primavera, J.H. 1996. Stable carbon and nitrogen isotope ratios of penaeid juveniles and primary producers in a riverine mangrove in Guimaras, Philippines. Bull. Mar. Sci. 58(3): 675-683.

Primrose, S., Woolfe, M., and Rollinson, S. 2010. Food forensics: methods for determining the authenticity of foodstuffs. Trends Food Sci. Technol. 21(12): 582-590. doi:10.1016/j.tifs.2010.09.006.

Schwamborn, R., and Criales, M.M. 2000. Feeding strategy and daily ration of juvenile pink shrimp (Farfantepenaeus duorarum) in a South Florida seagrass bed. Mar. Biol. 137(1): 139-147. doi:10.1007/s002270000317.

Serrano, R., Blanes, M.A., and Orero, L. 2007. Stable isotope determination in wild and farmed gilthead sea bream (Sparus aurata) tissues from the western Mediterranean. Chemosphere, 69(7): 1075-1080. doi:10.1016/j.chemosphere. 2007.04.034. PMID:17532023.

Stenroth, P., Holmqvist, N., Nyström, P., Berglund, O., Larsson, P., and Granéli, W. 2006. Stable isotopes as an indicator of diet in omnivorous crayfish (Pacifastacus leniusculus): the influence of tissue, sample treatment and season. Can. J. Fish. Aquat. Sci. 63(4): 821-831. doi:10.1139/f05-265.

Stern, S., and Sonnenholzner, S. 2011. Semi-intensive shrimp culture: the history of shrimp farming in Ecuador. In The shrimp book. Edited by V. Alday-Sanz. Nottingham University Press, Nottingham, UK. pp. 207-232.

USDS. 2010. U.S. withdraws Mexican shrimp importation certification under sea turtle protection law [online]. Press release 25 March 2010. United States Department of State. Available from http://www.state.gov/r/pa/prs/ps/ 2010/03/139081.htm [accessed 2 March 2013].

USGS. 2014. Isotopic reference materials and calibration services [online]. United States Geological Survey, Isotope Laboratory, Reston, Va. Available from http:/ isotopes.usgs.gov/lab/referencematerials.html [accessed 18 February 2014].

Vinci, G., Preti, R., Tieri, A., and Vieri, S. 2013. Authenticity and quality of animal origin food investigated by stable-isotope ratio analysis. J. Sci. Food Agric. 93(3): 439-448. doi:10.1002/jsfa.5970.

Woolfe, M., and Primrose, S. 2004. Food forensics: using DNA technology to combat misdescription and fraud. Trends Biotechnol. 22(5): 222-226. doi:10. 1016/j.tibtech.2004.03.010. PMID:15109807. 